DOI: $10.20472 / S S .2016 .5 .4 .001$

\title{
THE LOCATION OF PUBLIC MATERNAL HEALTH CARE FACILITIES AND MATERNAL MORTALITY IN IBADAN METROPOLIS, NIGERIA.
}

\section{MODUPE AYOADE}

\begin{abstract}
:
This paper examines the location, distributional pattern, and level of supply of public maternal health care facilities and skilled maternal health care workers in relation to the population of women of reproductive age in Ibadan Metropolis. The pattern of maternal mortality and its relationship with the level of availability of maternal health care services is also examined. GIS mapping techniques, rank correlation and the location quotient technique were employed in analyzing data. Results show that all the Local Government Areas especially Ona-Ara and Ibadan Southeast are deprived in terms of the provision of public maternal health care facilities and skilled maternal health care workers. Findings also suggest that there are other factors contributing to the high rate of maternal mortality in Ibadan.
\end{abstract}

\section{Keywords:}

Location, Public Maternal Health Care Services, Maternal Mortality, GIS, Ibadan, Nigeria

JEL Classification: I14, I15, I19

\section{Authors:}

MODUPE AYOADE, University of Ibadan, Nigeria, Email: ayoadema@yahoo.co.uk

\section{Citation:}

MODUPE AYOADE (2016). The location of public maternal health care facilities and maternal mortality in Ibadan metropolis, Nigeria.. International Journal of Social Sciences, Vol. V(4), pp. 1-18., 10.20472/SS.2016.5.4.001 


\section{INTRODUCTION}

Poor planning in the location and allocation of maternal health care resources has been identified in the literature as a major obstacle to attempts at reducing maternal mortality in developing countries (Ayeni and Rushton, 1985; Ikporukpo, 1987; Okafor, 1990; 1991; Gupta et al, 2003; Maguns, 2008; Comber, 2011). This is mainly due to the fact that the provision of maternal health care services is often characterized by issues of parochialism and corruption. Consequently, questions such as 'how many facilities are needed, who gets what and where' have been largely ignored in health care policies and strategies resulting in a situation where accessibility is poor and maximum coverage is not achieved. In 2013 Nigeria accounted for $14 \%$ of the world's total number of maternal deaths making Nigeria the country with the highest number of maternal deaths in sub Saharan Africa and about the second highest worldwide (WHO, 2014). Maternal mortality rates are as high as 3,380 and 3,525 maternal deaths per 100,000 live births in the cities of Lagos and kano. This is in spite of considerable investments in the maternal health care service delivery system and the adoption of programmes such as the safe motherhood initiative (1990) and the making pregnancy safer (MPS) initiative (2001).

In Nigeria, the provision of maternal health care services is based on a three tier hierarchical system. At the bottom of the hierarchy are primary health care centres such as maternity clinics which serve as the first contact for most women to maternal health care. These clinics focus on the early detection and prevention of direct and indirect obstetric diseases and maintenance of overall health. Since they handle issues which occur frequently they tend to be ubiquitous. More complex pregnancy related complications are handled by secondary health care centers which offer emergency treatment and critical care or by tertiary health centers that provide very specialized services for handling very serious complications. Like in most third world countries maternal health care is also obtained from traditional health care centres. Although they are more common in rural areas, they are also widely used in cities. Skilled health care workers play a critical role in the provision of ante natal and post natal care in Nigeria. They include doctors, nurses and midwives who have been trained to proficiency in the skills necessary to manage pregnancies and deliveries. In the rural areas, traditional birth attendants (TBAs) and community health workers (CHWs) provide support to pregnant women especially during childbirth as well as a lot of emotional support and comfort often lacking in the orthodox health care system

Deciding where and how much maternal health care services to provide is therefore a critical step in improving the health and survival chances of Nigerian women before, during and after giving birth. However such decisions cannot be successfully made without assessing the present supply and distribution of maternal health care services in light of population size, present and projected demand etc. The best location in the supply of these facilities is therefore one that enhances accessibility while ensuring that the quality and quantity of services needed are met (Marsh, 1994; Daskin and Dean, 2004; Mainardi, 2007). Penchansky and Thomas (1981) 
recognized five dimensions of accessibility: Physical distance/access, availability, affordability, acceptability and accommodation/quality of services. The last three factors which are aspatial factors reflect socio- economic, demographic, cultural and religious factors in the access to health facilities while accessibility and availability factors are spatial in nature and are frequently considered together under the term 'spatial accessibility' in location studies (Guagliardo, 2004; Higgs,2004; Okafor,2012). Surprisingly, most studies in Nigeria seem to focus on the demand side i.e. on socio-economic, cultural, religious and political factors that influence realized accessibility without fully recognizing that the location of facilities plays a major role in determining their use and effectiveness. Also, studies have not examined the relationship between the distribution of maternal health care facilities and maternal health outcomes such as maternal mortality. In an earlier study, Ayoade (2014) modeled the walking and driving service areas of public maternal health care facilities in Ibadan metropolis, Nigeria using the circular buffer method and assessed their distributional pattern using nearest neighbor analysis and Moran's I statistic. Results showed that many women reside within $20 \mathrm{~km}$ of public maternal health care facilities even though the facilities are randomly distributed. This paper examines the provision of both maternal health care facilities and skilled birth attendants in relation to the population of women aged 15-49 years as well as the relationship between the availability of these maternal health care services and the rate of maternal mortality in Ibadan, Nigeria. The objective of this study is to examine the location and distributional pattern of public maternal health care facilities and skilled birth attendants in relation to the pattern of maternal mortality in Ibadan metropolis, Nigeria.

\section{Study Area}

The study was carried out in Ibadan, the capital city of Oyo State located approximately on Longitude $3^{\circ} 58^{\prime}$ East of the Greenwich Meridian and Latitude $7^{\circ}$ 23 ' North of the equator(Fig 1). Since its emergence in 1829, Ibadan has continued to grow both in population and areal extent. Today, the metropolitan area of Ibadan comprises eleven local Government areas. Five of these constitute the core area of Ibadan metropolis. These are Ibadan Southwest with headquarters in Ring Road; Ibadan Northwest with headquarters in Onireke; Ibadan North with headquarters at Bodija; Ibadan Northeast with headquarters along Iwo Road; and Ibadan Southeast with headquarters at Mapo. The other six local government areas covering parts of the city and the surrounding rural areas are Akinyele, Egbeda, Lagelu, Oluyole, Ona Ara, and Ido Local Government Areas. According to the 2006 census, Ibadan has a total population of 2,559,853 made up of 1,295,243 females out of whom 677,142 $(52.28 \%)$ are of child bearing age. There is therefore need to ensure that there is an adequate supply and optimal distribution of maternal health care services in Ibadan metropolis. 
Fiqure 1: Map of Study Area

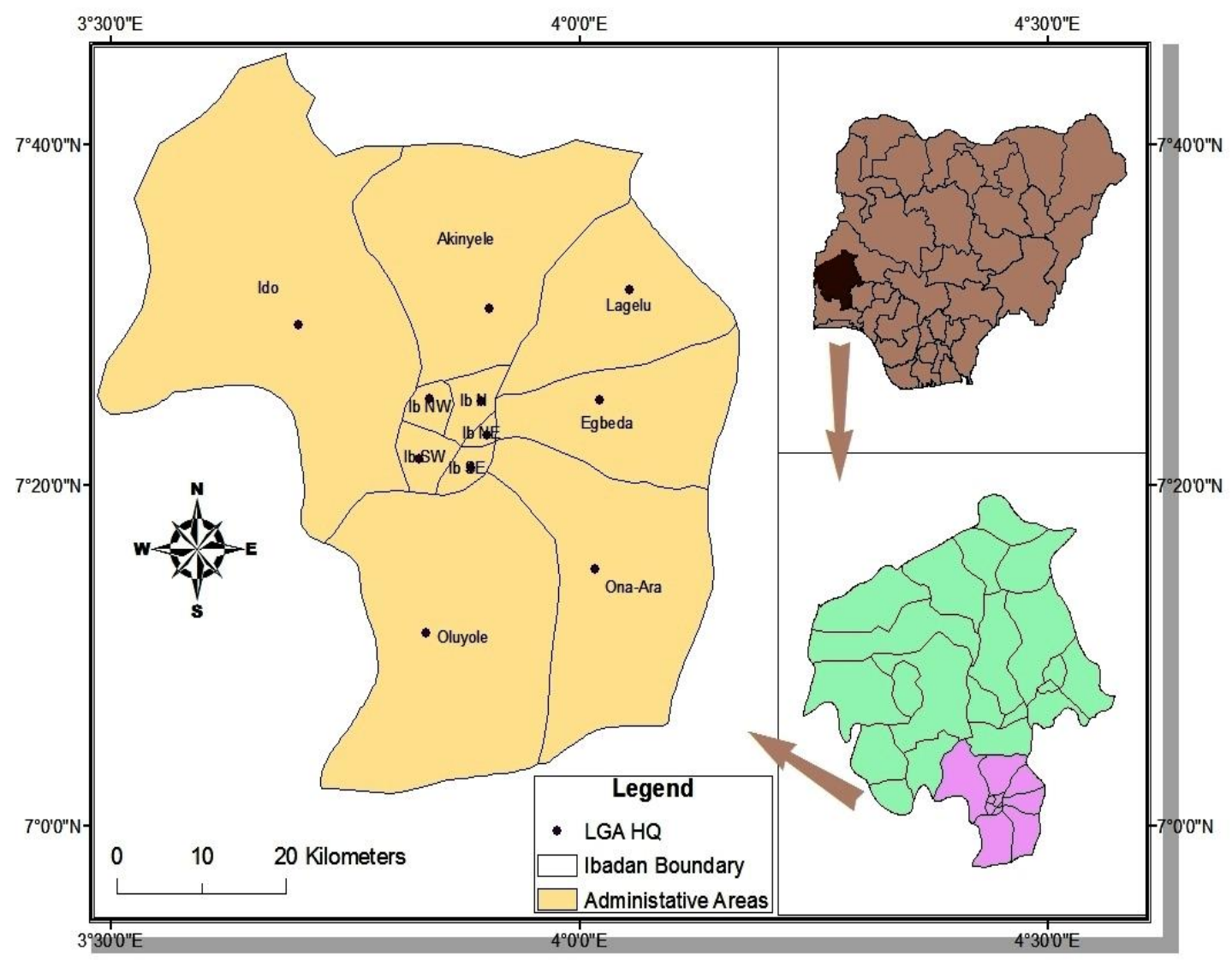

Source: Author's Field work

\section{METHODOLOGY}

The following data were collected for this study from both primary and secondary sources:

1) The population figures for women aged 15- 49 years for each Local Government Area (LGA) was obtained from the 2006 population and housing census priority table volume IV published by the Nigerian Population Commission in 2010. (Note: 2006 population census figures are the most recent census figures available).

2) Scanned administrative map of Ibadan was digitized and geo- referenced

3) Locations of all public maternal health facilities in lbadan including information on ownership and type of facility were collected from the Oyo state ministry of health.

4) Data on the number of skilled birth attendants of various categories in each public maternal health care facility in Ibadan. as well as records of the number of 
maternal deaths, live births and deliveries attended by skilled maternal health care personnel from 2009-2011 were also obtained from the same source.

\section{Data Analysis and GIS Mapping Procedure}

Using ArcGIS 9.3 and Micosoft Excel as data processing tools, the mapping and analytical procedure designed for this study is schematically shown in Fig 2.

Figure 2: Cartographic Model showing Methodology

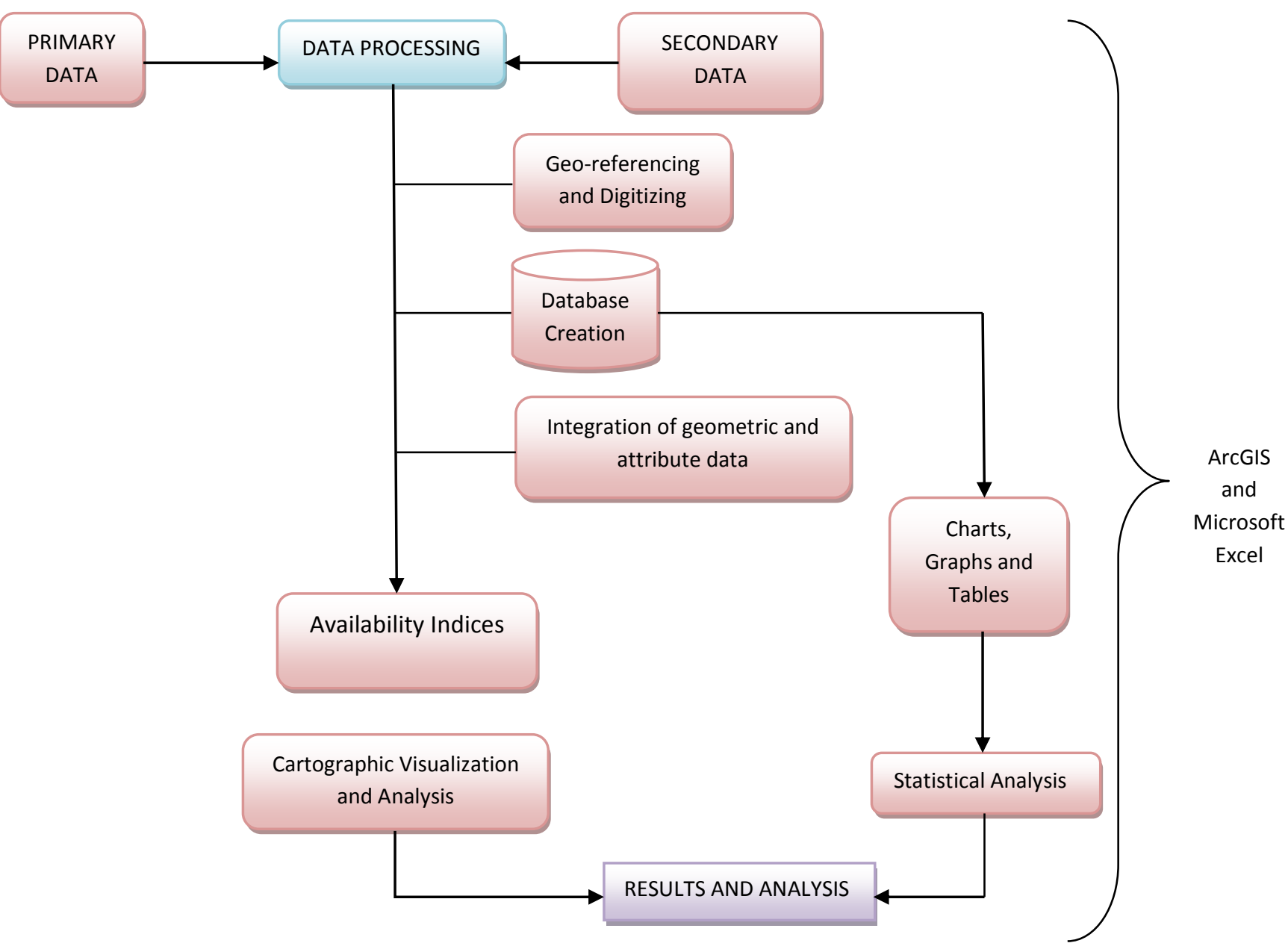

Rank correlation analysis was used to assess the level of association between the following:

a) Maternal mortality rates and number of public maternal health care facilities.

b) Maternal mortality rates and number of skilled maternal health care personnel.

c) Number of public maternal health care facilities and the number of women aged 15-49 years.

d) Number of skilled maternal health care personnel and the number of women aged 15-49 years. 
Data collected were further processed and analyzed as follows:

> Attribute data collected were entered into Microsoft excel, imported into ArcGIS for mapping. The supply of skilled birth attendants and facilities were expressed in terms of ratio to the female population aged 15-49 years and land area and assessed using classifications based on WHO standards (Table 1)

Table 1: Classification Classes and Values

\begin{tabular}{|l|l|l|l|}
\hline & \multicolumn{1}{|c|}{ Indicators } & Range of values & \multicolumn{1}{c|}{ Classes } \\
\hline 1 & Ratio of public maternal health care & $<500$ & Very good \\
\cline { 3 - 4 } facilities to female population & $500-1249$ & Good \\
\cline { 3 - 4 } & & $1250-2000$ & Moderate \\
\cline { 3 - 4 } & & $>2000$ & Poor \\
\hline 2 & Ratio of skilled Maternal health care & $<435$ & Very good \\
\cline { 3 - 4 } & personnel to female population & $435-623$ & Good \\
\cline { 3 - 4 } & & $624-812$ & Moderate \\
\cline { 3 - 4 } & & $>812$ & Poor \\
\hline
\end{tabular}

Values obtained were then mapped. Maps obtained help reveal the spatial distribution and level of availability of public maternal health care services. To further examine the degree of availability of maternal health care services the location quotient (L.Q) technique was used. Location quotient values less than 1.0 indicate that the LGA concerned is marginally disadvantaged in the provision of facilities while values more than 1.0 indicate that the LGA concerned is marginally favoured in the provision of facilities.

It is important to note a few limitations of this study which could be addressed in future research particularly with the availability of more detailed data. First of all, the population-based measures used are based on the assumption that services are equally available although in reality accessibility varies over space and with differences in socioeconomic characteristics. They also do not consider the migration of patients across administrative boundaries. Secondly, the lack of data especially at ward levels led to the use of aggregated data on a LGA basis, hence internal/community level variations could not be examined.

\section{RESULTS AND DISCUSSION}

\section{The Spatial Distribution of Public Maternal Health Care Facilities and Skilled Birth Attendants in Ibadan metropolis.}

In terms of supply, Ibadan has 240 public maternal health care facilities out of which $231(96 \%)$ are primary facilities, $7(2.92 \%)$ are secondary facilities and $2(0.83 \%)$ are tertiary public maternal health care facilities. Most (208) of these facilities are owned by the Local Government, 23 facilities are owned by the Oyo state Government and 9 facilities by the federal Government. In terms of spatial distribution, only six Local Government Areas (Akinyele, Egbeda, Ibadan North, Ibadan Southwest, Lagelu and Oluyole) have at least one secondary maternal health care facility (with the exception 
of Lagelu that has two secondary maternal health care facilities) while the only two tertiary facilities, the University College Hospital and Adeoyo state hospital are located in Ibadan North. The former is owned by the Federal Government and the latter by the Oyo state Government. In total most facilities (35) are located in Ibadan Southwest while Ibadan Southeast has the lowest (12) number of facilities. This implies that 104 (43\%) of public maternal health care facilities in Ibadan are located in the city core. Improving the supply and quality of maternal health care in Ibadan will therefore require either equipping Local Governments to handle the responsibility of provision adequately or sharing the burden of provision more equally among the three tiers of Government.

Obviously, no health intervention can be successful without an adequate supply of an effective health care workforce, hence the focus on examining the distribution of skilled birth attendants such as consultants, doctors, nurses and midwives. These play a major role in maternal health care delivery by catering to women during prenatal, intra natal and postnatal periods (Sharma, 2009). It was discovered that the 62 consultants, 528 doctors and 2,098 nurses/midwives in lbadan are overall adequate but not well allocated. For instance, 1,937 of the 2,688 skilled maternal health care workers are located in Ibadan North. In fact, more than half $460(87 \%)$ of doctors, $1,431(68 \%)$ of nurses/midwives and $46(74 \%)$ of consultants are in Ibadan North. A closer inspection shows that 44 out of the 46 consultants (95.65\%), 441 out of the 460 doctors (95.87\%) and 1,348 out of the 1,431 nurses/midwives $(94.20 \%)$ are stationed in the only two tertiary hospitals i.e. $\mathrm{UCH}$ and Adeoyo also located in Ibadan North. There also appears to be a slight concentration of skilled maternal health care workers in Ibadan Southwest where a total of 419 skilled maternal health care workers are stationed comprising 375(17.9\%) nurses/midwives, 31 (5.9\%) doctors and $13(21 \%)$ consultants. Hence there is a wide gap in the provision of skilled maternal health care workers between Ibadan North and other Local Government Areas. On the other hand, Local Government Areas with the lowest number of maternal health care workers are Ido (11), Ona-Ara (11) and Ibadan Southeast (14). Jointly they have a total of only $36(1.3 \%)$ which is comparatively very small. Majority of the skilled maternal health care workers in the study area are nurses/midwives. Although, they provide critical medical support especially during the delivery process, we cannot underestimate the need for an adequate supply of skilled and experienced doctors critical for handling more challenging obstetric cases.

\section{The Availability of Public Maternal Health Care Facilities and Skilled Birth Attendants in Ibadan Metropolis.}

It was discovered that in relation to the 677,142 women of reproductive age, Ibadan has a an average of one public maternal health care facility per 2,821 women aged 15-49 years which exceeds the WHO standard of a maximum of $1: 2,000$ thus indicating that the overall supply of public maternal health care facilities in Ibadan is inadequate. On a LGA basis, Ibadan Southeast has the poorest level of availability 
with the highest number of women aged $15-49$ years per facility $(1: 5,785)$ while Ido has the best level of availability with the lowest number of women aged 15-49 years per facility $(1: 1,395)$. As shown in Table 2a, 8 LGAs were found to be disadvantaged in the provision of public maternal health care facilities when compared with WHO standards (Table 2a).

Table 2a: The Number of Women aged 15-49 years per Public Maternal Health Care Facility in Ibadan

\begin{tabular}{|c|c|c|c|c|c|c|c|c|c|c|c|}
\hline $\begin{array}{c}\text { Local } \\
\text { Government } \\
\text { Area }\end{array}$ & $\begin{array}{c}\text { Female } \\
\text { population } \\
15-49\end{array}$ & $\begin{array}{l}\text { Total } \\
\text { PMHCF }\end{array}$ & $\begin{array}{c}\text { No of } \\
\text { Women per } \\
\text { Facility }\end{array}$ & $\begin{array}{c}\text { Per } \\
10,000 \\
\text { women } \\
15-49\end{array}$ & $\begin{array}{l}\text { Primary } \\
\text { PMHCF }\end{array}$ & $\begin{array}{c}\text { No of } \\
\text { Women } \\
\text { per Primary } \\
\text { Facility }\end{array}$ & $\begin{array}{c}\text { Per } \\
10,000 \\
\text { women }\end{array}$ & $\begin{array}{l}\text { Secondary } \\
\text { PMHCF }\end{array}$ & $\begin{array}{c}\text { No of } \\
\text { Women per } \\
\text { Secondary } \\
\text { Facility }\end{array}$ & $\begin{array}{l}\text { Per } \\
10,000 \\
\text { women } \\
15-49\end{array}$ & $\begin{array}{l}\text { Tertiary } \\
\text { PMHCF }\end{array}$ \\
\hline Akinyele & 53,215 & 29 & 1,835 & 5.45 & 28 & $1,900.54$ & 5.26 & 1 & 53,215 & 0.19 & \\
\hline Egbeda & 77,224 & 23 & $3,357.57$ & 2.98 & 22 & $3,510.18$ & 2.85 & 1 & 77,224 & 0.13 & \\
\hline Ibadan North & 84,484 & 18 & $4,693.56$ & 2.13 & 16 & $5,280.25$ & 1.89 & & & & 2 \\
\hline Ibadan NE & 88,498 & 24 & $3,687.42$ & 2.71 & 23 & $3,847.74$ & 2.59 & 1 & 88,498 & 0.11 & \\
\hline Ibadan NW & 41,609 & 15 & $2,773.93$ & 3.60 & 15 & $2,773.93$ & 3.60 & & & & \\
\hline Ibadan SE & 69,421 & 12 & $5,785.08$ & 1.73 & 12 & $5,785.08$ & 1.73 & & & & \\
\hline Ibadan SW & 76,136 & 35 & $2,175.31$ & 4.59 & 34 & $2,239.29$ & 4.47 & 1 & 76,136 & 0.13 & \\
\hline Ido & 26,507 & 19 & $1,395.11$ & 7.17 & 19 & $1,395.11$ & 7.17 & & & & \\
\hline Lagelu & 38,752 & 18 & $2,152.89$ & 4.64 & 16 & 2,422 & 4.13 & 2 & 19,376 & 0.52 & \\
\hline Oluyole & 52,505 & 27 & $1,944.63$ & 5.14 & 26 & $2,019.42$ & 4.95 & 1 & 52,505 & 0.19 & \\
\hline Ona-Ara & 68,791 & 20 & $3,439.55$ & 2.91 & 20 & $3,439.55$ & 2.91 & & & & \\
\hline TOTAL & 677,142 & 240 & $2,821.43$ & 3.54 & 231 & $2,931.35$ & 3.41 & 7 & 96,734 & 0.10 & 2 \\
\hline
\end{tabular}

Prominent among them are Ibadan Southeast $(1: 5,785)$, Ibadan North $(1: 4,693)$ and Ibadan Northeast $(1: 3,687)$. On the other hand, Oluyole $(1: 1,944)$, Akinyele $(1: 1,835)$ and Ido $(1: 1,395)$ were found to be moderately advantaged. However, this was not the case when compared to land area size (Table 2b). Public maternal health care facilities in Ido LGA were found to have very wide catchment areas with a land area $\left(\mathrm{Km}^{2}\right)$ per facility of 1:53.21 followed by Oluyole (1:23.53) and Ona-Ara (1:21.29). On the other hand, Ibadan Northeast have the best coverage with one facility serving $2.14 \mathrm{~km}^{2}$ followed by Ibadan Southwest (1:3.81), Ibadan Northwest(1:3.93), Ibadan Southeast $(1: 4.85)$ and Ibadan North (1:7.36). This suggests that women resident in the city core will not have to travel as far as their counterparts in other Local Government Areas to available public maternal health care facilities (Fig $3 a \& b$ ). 
Table 2b: Land Area $\left(\mathrm{km}^{2}\right)$ Per Public Maternal Health Care Facility in Ibadan

\begin{tabular}{|c|c|c|c|c|c|c|c|}
\hline $\begin{array}{c}\text { Local } \\
\text { Government } \\
\text { Area }\end{array}$ & $\begin{array}{l}\text { Land Area } \\
\left(\mathrm{km}^{2}\right)\end{array}$ & $\begin{array}{l}\text { Total } \\
\text { PMHCF }\end{array}$ & $\begin{array}{l}\text { Land Area } \\
\text { per } \\
\text { Facility }\end{array}$ & $\begin{array}{l}\text { Primary } \\
\text { PMHCF }\end{array}$ & $\begin{array}{l}\text { Land Area } \\
\text { per Primary } \\
\text { Facility }\end{array}$ & $\begin{array}{c}\text { Secondary } \\
\text { PMHCF }\end{array}$ & $\begin{array}{l}\text { Land Area per } \\
\text { Secondary } \\
\text { Facility }\end{array}$ \\
\hline Akinyele & 464.892 & 29 & 16.03 & 28 & 16.60 & 1 & 464.892 \\
\hline Egbeda & 185.508 & 23 & 8.07 & 22 & 8.43 & 1 & 185.508 \\
\hline Ibadan North & 132.5 & 18 & 7.36 & 16 & 8.28 & & \\
\hline Ibadan NE & 51.25 & 24 & 2.14 & 23 & 2.23 & 1 & 51.25 \\
\hline Ibadan NW & 59.001 & 15 & 3.93 & 15 & 3.93 & & \\
\hline Ibadan SE & 58.251 & 12 & 4.85 & 12 & 4.85 & & \\
\hline Ibadan SW & 133.5 & 35 & 3.81 & 34 & 3.93 & 1 & 133.5 \\
\hline Ido & 1010.9549 & 19 & 53.21 & 19 & 53.21 & & \\
\hline Lagelu & 310.850 & 18 & 17.27 & 16 & 19.43 & 2 & 15.925 \\
\hline Oluyole & 635.384 & 27 & 23.53 & 26 & 24.44 & 1 & 635.384 \\
\hline Ona-Ara & 425.944 & 20 & 21.29 & 20 & 21.29 & & \\
\hline TOTAL & 3,468 & 240 & 14.45 & 231 & 15.01 & 7 & 495.43 \\
\hline
\end{tabular}

Similarly, location quotient scores showed that six Local Government Areas are marginally advantaged. Prominent among them are Ido (2.03) and Oluyole (1.45) while disadvantaged areas include Ibadan Southeast (0.49), Ibadan North (0.60) and Ibadan Northeast (0.77) probably because of the large number of women aged 1549 years located in these areas (Fig 3c). On the other hand, the study area as a whole has a very good supply (1:252) of skilled maternal health care workers in relation to the population of women aged 15-49 years when compared with WHO standards (1:435). However, on a LGA basis large variations in supply are evident. Table $3 a$ shows that Ona-Ara $(1: 6,253)$, Ibadan Southeast $(1: 4,958)$ and Egbeda $(1: 3,217)$ have the poorest level of supply of total skilled maternal health care workers per women aged 15-49 years while Ibadan North (1:43), Southwest (1:181) and Northwest(1:361) have a very good level of availability. In relation to land area, Ibadan has a land area $\left(\mathrm{Km}^{2}\right)$ per personnel of 1:1.29 indicating that on the average skilled maternal health care workers are in close proximity to women of reproductive age. However, at the LGA level, Ido and Ona-ara have the worst level of availability of doctors, nurses/midwives and consultants in terms of land area served (Table 3b). On the other hand, the best supply of skilled maternal health care workers in terms of land area served is in Ibadan North (1:0.07), Ibadan Southwest (1:0.32), Northwest (1:0.51), Northeast (1:0.88) and Southeast (1:4.16), (Fig 4a \& b). 
Table 3a: The Number of Women aged 15-49 years to Skilled Maternal health Care Workers in Ibadan

\begin{tabular}{|c|c|c|c|c|c|c|c|c|c|c|c|c|c|}
\hline LGA & $\begin{array}{c}\text { Female } \\
\text { population } \\
15-49\end{array}$ & $\begin{array}{c}\text { Total } \\
\text { Skilled } \\
\text { Maternal } \\
\text { Health } \\
\text { Care } \\
\text { Workers }\end{array}$ & $\begin{array}{c}\text { No of } \\
\text { Women } \\
\text { per } \\
\text { Personnel }\end{array}$ & $\begin{array}{c}\text { Per } \\
10,000 \\
\text { women } \\
15-49\end{array}$ & $\begin{array}{l}\text { Nurses/ } \\
\text { Midwives }\end{array}$ & $\begin{array}{c}\text { No of } \\
\text { Women } \\
\text { per } \\
\text { Nurse/ } \\
\text { Midwife }\end{array}$ & $\begin{array}{l}\text { Per } \\
10,000 \\
\text { women } \\
15-49\end{array}$ & Consultants & $\begin{array}{c}\text { No of } \\
\text { Women } \\
\text { per } \\
\text { Consultant }\end{array}$ & $\begin{array}{c}\text { Per } \\
10,000 \\
\text { women } \\
15-49\end{array}$ & Doctors & $\begin{array}{c}\text { No of } \\
\text { Women } \\
\text { per } \\
\text { Doctor }\end{array}$ & $\begin{array}{c}\text { Per } \\
10,000 \\
\text { women } \\
15-49\end{array}$ \\
\hline $\begin{array}{c}\text { Akinyel } \\
\mathrm{e}\end{array}$ & 53,215 & 38 & $1,400.39$ & 7.14 & 35 & $\begin{array}{c}1,520.4 \\
3\end{array}$ & 6.58 & 1 & 53,215 & 0.19 & 2 & $26,607.5$ & 0.38 \\
\hline Egbeda & 77,224 & 24 & $3,217.67$ & 3.11 & 22 & $\begin{array}{c}3,510.1 \\
8\end{array}$ & 2.85 & & & & 2 & 38,612 & 0.26 \\
\hline $\begin{array}{l}\text { Ibadan } \\
\text { North }\end{array}$ & 84,484 & 1,937 & 43.62 & 229.27 & 1,431 & 59.04 & 169.38 & 46 & $1,836.61$ & 5.44 & 460 & 183.66 & 54.44 \\
\hline $\begin{array}{c}\text { Ibadan } \\
\mathrm{NE}\end{array}$ & 88,498 & 58 & $1,525.83$ & 6.55 & 54 & $\begin{array}{c}1,638.8 \\
5 \\
\end{array}$ & 6.10 & & & & 4 & $22,124.5$ & 0.45 \\
\hline $\begin{array}{c}\text { Ibadan } \\
\text { NW }\end{array}$ & 41,609 & 115 & 361.82 & 27.64 & 92 & 452.27 & 22.1 & 2 & $20,804.5$ & 0.48 & 21 & $1,981.38$ & 5.05 \\
\hline $\begin{array}{c}\text { Ibadan } \\
\text { SE }\end{array}$ & 69,421 & 14 & $4,958.64$ & 2.02 & 13 & $\begin{array}{c}5,340.0 \\
8\end{array}$ & 1.87 & & & & 1 & 69,421 & 0.14 \\
\hline $\begin{array}{c}\text { Ibadan } \\
\text { SW }\end{array}$ & 76,136 & 419 & 181.71 & 55.03 & 375 & 203.03 & 49.25 & 13 & $5,856.62$ & 1.71 & 31 & 2,456 & 4.07 \\
\hline Ido & 26,507 & 11 & $2,409.73$ & 4.15 & 10 & $2,650.7$ & 3.77 & & & & 1 & 26,507 & 0.38 \\
\hline Lagelu & 38,752 & 28 & 1,384 & 7.23 & 26 & $\begin{array}{c}1,490.4 \\
6\end{array}$ & 6.71 & & & & 2 & 19,376 & 0.52 \\
\hline Oluyole & 52,505 & 33 & $1,591.06$ & 6.29 & 30 & $\begin{array}{c}1,750.1 \\
7\end{array}$ & 5.71 & & & & 3 & $\begin{array}{c}17,501.6 \\
7\end{array}$ & 0.57 \\
\hline $\begin{array}{c}\text { Ona- } \\
\text { Ara }\end{array}$ & 68,791 & 11 & $6,253.73$ & 1.60 & 10 & $6,879.1$ & 1.45 & & & & 1 & 68,791 & 0.15 \\
\hline TOTAL & 677,142 & 2,688 & 251.91 & 39.69 & 2,098 & 322.76 & 30.98 & 62 & 10,921 & 0.92 & 528 & $1,282.47$ & 7.80 \\
\hline
\end{tabular}

Table 3b: Land Area per km2 to skilled maternal Health Care Personnel in Ibadan

\begin{tabular}{|c|c|c|c|c|c|c|c|c|c|}
\hline $\begin{array}{c}\text { Local } \\
\text { Government } \\
\text { Area }\end{array}$ & $\begin{array}{l}\text { Land Area } \\
\left(\mathrm{km}^{2}\right)\end{array}$ & $\begin{array}{c}\text { Total Skilled } \\
\text { Maternal } \\
\text { Health Care } \\
\text { Workers } \\
\end{array}$ & $\begin{array}{l}\text { Land Area } \\
\text { per } \\
\text { Personnel }\end{array}$ & Nurses/Midwives & $\begin{array}{l}\text { Land Area per } \\
\text { Nurse/Midwife }\end{array}$ & Doctors & $\begin{array}{l}\text { Land } \\
\text { Area per } \\
\text { Doctor }\end{array}$ & Consultants & $\begin{array}{l}\text { Land Area } \\
\text { per } \\
\text { Consultant }\end{array}$ \\
\hline Akinyele & 464.892 & 38 & 12.23 & 35 & 13.28 & 2 & 232.45 & 1 & 464.89 \\
\hline Egbeda & 185.508 & 24 & 7.73 & 22 & 8.43 & 2 & 92.75 & & \\
\hline Ibadan North & 132.5 & 1,937 & 0.07 & 1,431 & 0.09 & 460 & 0.29 & 46 & 2.88 \\
\hline Ibadan NE & 51.25 & 58 & 0.88 & 54 & 0.95 & 4 & 12.81 & & \\
\hline Ibadan NW & 59.001 & 115 & 0.51 & 92 & 0.64 & 21 & 2.81 & 2 & 29.50 \\
\hline Ibadan SE & 58.251 & 14 & 4.16 & 13 & 4.48 & 1 & 58.25 & & \\
\hline Ibadan SW & 133.5 & 419 & 0.32 & 375 & 0.36 & 31 & 4.31 & 13 & 10.27 \\
\hline Ido & 1010.9549 & 11 & 91.90 & 10 & 101.09 & 1 & 1010.95 & & \\
\hline Lagelu & 310.850 & 28 & 11.10 & 26 & 11.96 & 2 & 155.43 & & \\
\hline Oluyole & 635.384 & 33 & 19.25 & 30 & 21.18 & 3 & 211.79 & & \\
\hline Ona-Ara & 425.944 & 11 & 38.72 & 10 & 42.59 & 1 & 425.94 & & \\
\hline TOTAI & 3,468 & 2,688 & 1.29 & 2,098 & 1.65 & 528 & 6.57 & 62 & 55.94 \\
\hline
\end{tabular}




\section{Figure 3}

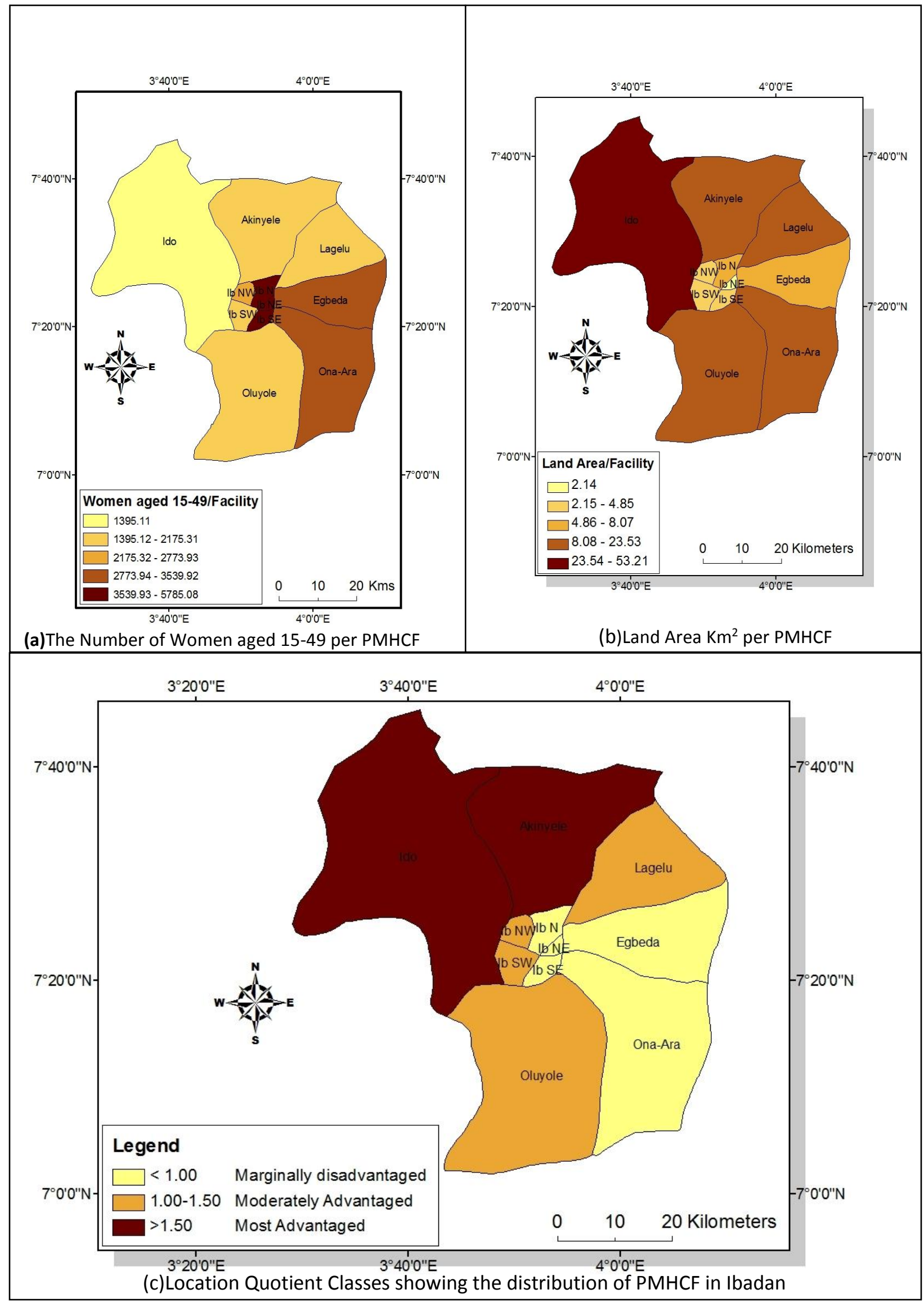

Source: Author's Field work 
Figure 4

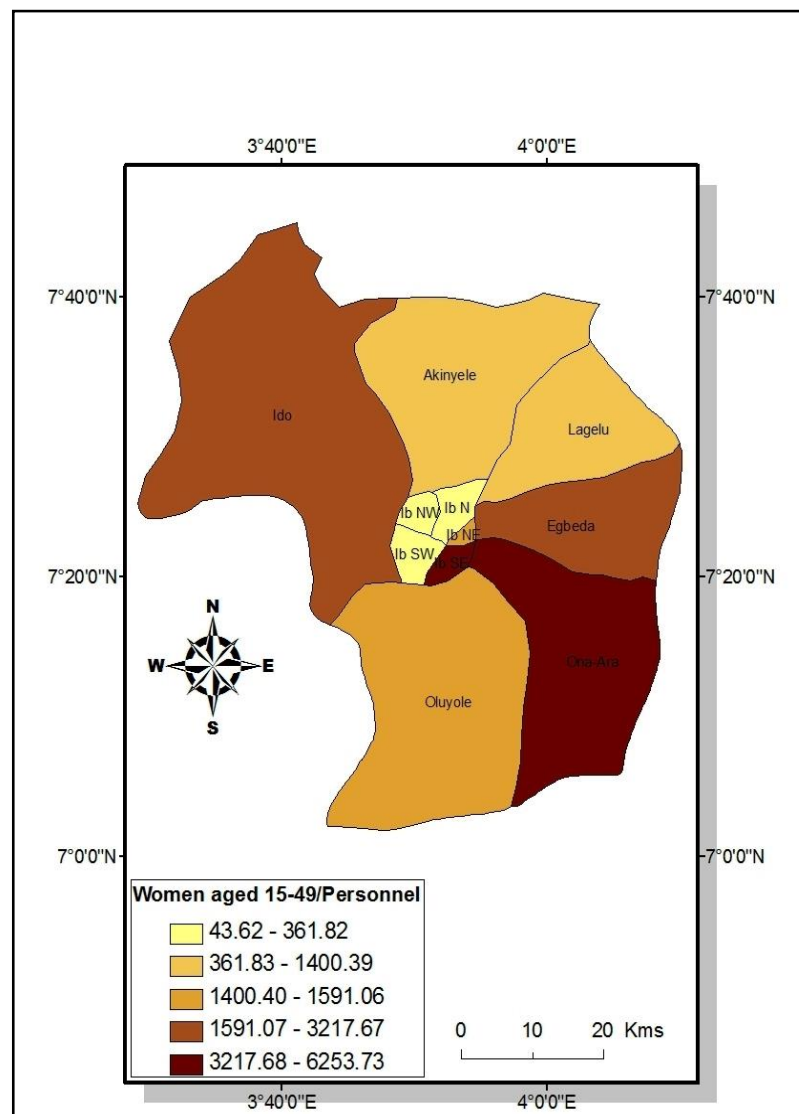

(a)The Number of Women aged 15-49 per Personnel

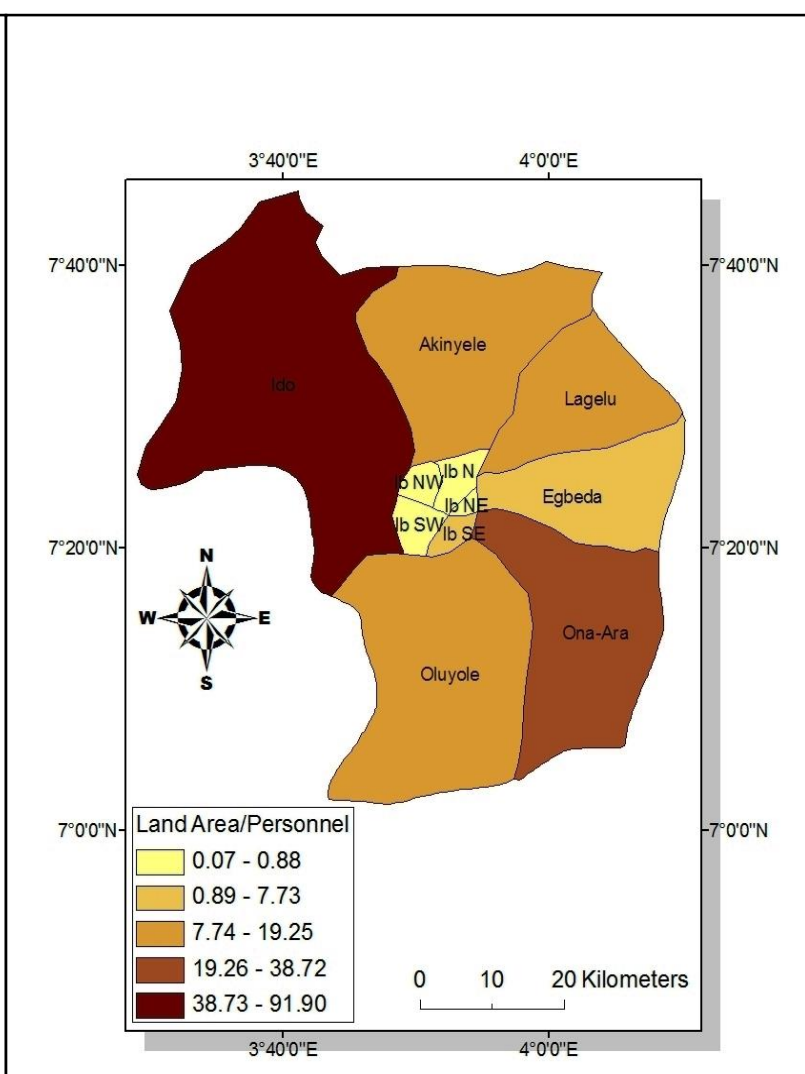

(b)Land Area $\mathrm{Km}^{2}$ per Personnel

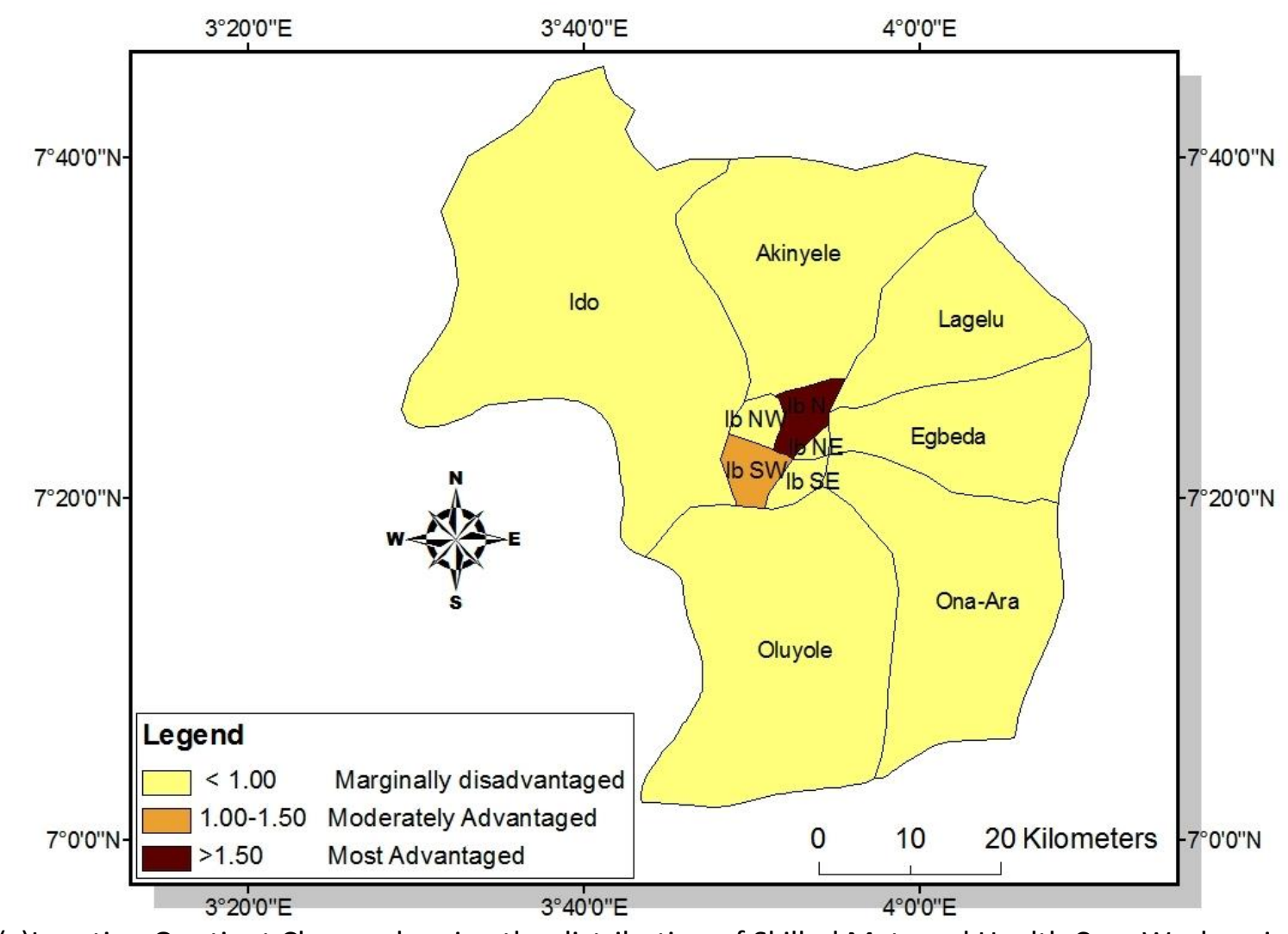

(c)Location Quotient Classes showing the distribution of Skilled Maternal Health Care Workers in Ibadan

\section{Source: Author's Field work}


Likewise, the location quotient scores showed that Ibadan North and Southwest are clearly marginally advantaged while Ido, Ona-Ara, Ibadan Southeast and Egbeda are largely deprived access to an adequate supply of skilled maternal health care workers (Fig 4c). The summary of location quotient scores for the 11 Local Government Areas showed spatial disparities in the location of public maternal health care services (Table $4 a \& b$ ).

Table 4a: Summation of Location Quotient Scores by Local Government Area in Ibadan

\begin{tabular}{|c|c|c|c|c|c|c|c|}
\hline LGA & Primary & Secondary & Tertiary & Consultants & Practitioners & Nurses/Midwives & $\begin{array}{c}\text { LGA } \\
\text { with LQ } \\
>1.00\end{array}$ \\
\hline Akinyele & 1.54 & 1.82 & & 0.21 & 0.05 & 0.21 & 2 \\
\hline Egbeda & 0.83 & 1.25 & & & 0.03 & 0.09 & 1 \\
\hline Ibadan North & 0.56 & & 8.01 & 5.94 & 6.98 & 5.47 & 4 \\
\hline Ibadan North east & 0.76 & 1.09 & & & 0.06 & 0.20 & 1 \\
\hline Ibadan Northwest & 1.05 & & & 0.53 & 0.65 & 0.71 & 1 \\
\hline Ibadan Southeast & 0.51 & & & & 0.02 & 0.06 & 0 \\
\hline Ibadan Southwest & 1.31 & 1.27 & & 1.87 & 0.52 & 1.59 & 4 \\
\hline Ido & 2.10 & & & & 0.05 & 0.12 & 1 \\
\hline Lagelu & 1.21 & 4.99 & & & 0.07 & 0.22 & 2 \\
\hline Oluyole & 1.45 & 1.84 & & & 0.07 & 0.18 & 2 \\
\hline
\end{tabular}

Table 4b: Classification of Local Government Areas based on their Total Number of Location Quotient Scores $>1.00$

\begin{tabular}{|c|c|c|}
\hline $\begin{array}{c}\text { Classification of LGAs } \\
\text { with LQ }>1.00\end{array}$ & Number of LGAs & Names of Local Government Areas \\
\hline$<2$ & 6 & Egbeda, Ibadan NE, Ibadan NW, Ibadan SE, Ido, Ona-Ara \\
\hline $2-3$ & 3 & Akinyele, Lagelu, Oluyole \\
\hline$>3$ & 2 & Ibadan North, Ibadan Southwest \\
\hline
\end{tabular}

It was found that all the Local Government Areas are deprived either in terms of the provision of public maternal health care facilities or level of availability of skilled maternal health care workers. Overall, Ibadan North and Southwest are largely favoured in the provision of these services while Ona-Ara, Ibadan Southeast, Northwest, Northeast and Egbeda are the most deprived areas. Based on a classification of location quotient scores, Ibadan was grouped into three regions of varying levels of availability and accessibility to public maternal health care services (Fig5). Results from the rank correlation analysis showed that the relationship between the supply of public maternal health care facilities and the number of women aged 15-49 years in Ibadan is not significant ( $r s=0.23$ ). The relationship between the provision of skilled maternal health care workers and the number of women aged 15-49 is also not significant $(r s=0.42$ ). This suggests that the provision of maternal health care facilities and the deployment of maternal health care workers have not taken into cognizance the population of women beneficiaries. 
Figure 5: Regions Based on the Classification of the Total Number of Location Quotient Scores $>1.00$

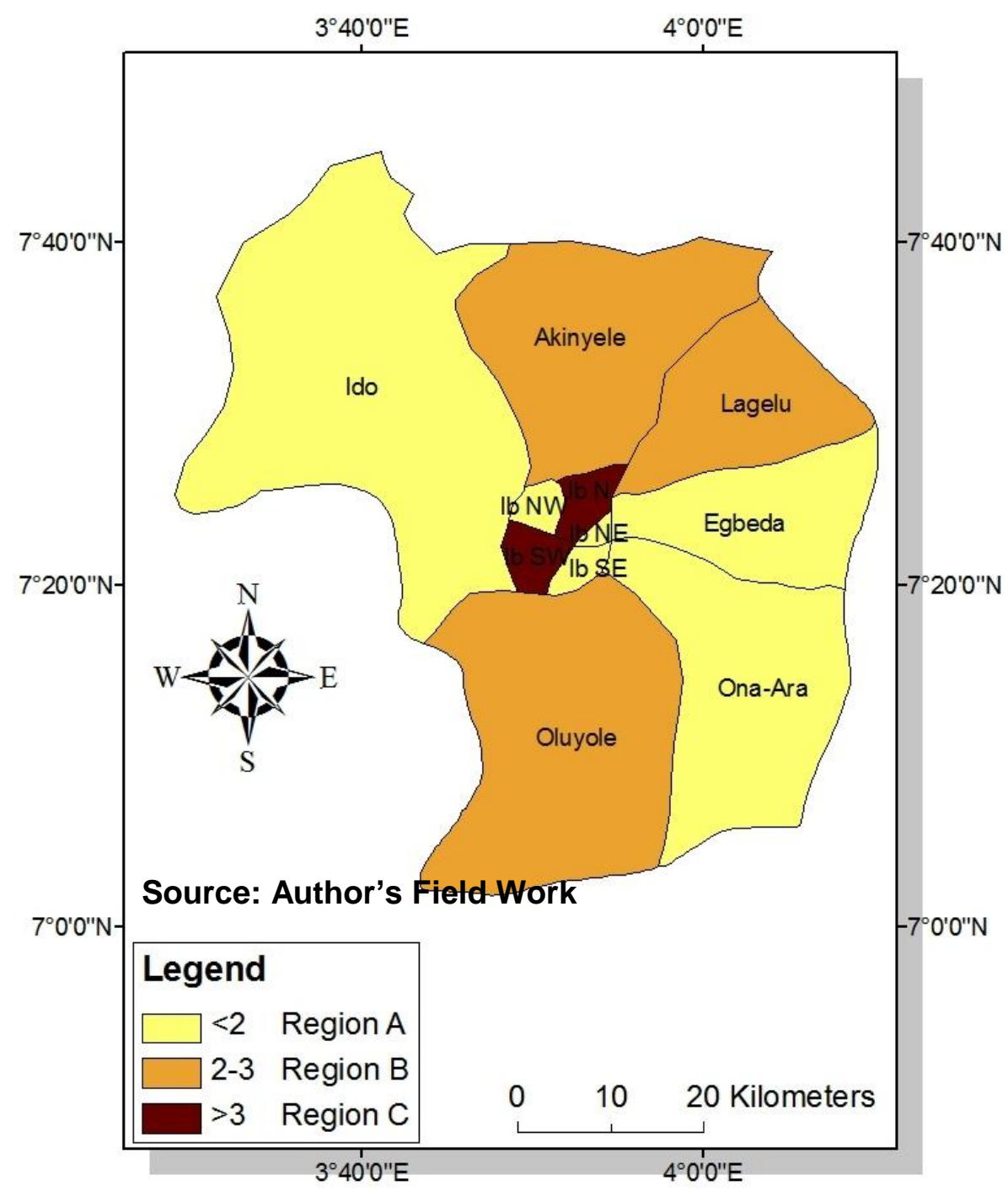

\section{Maternal Mortality in Ibadan Metropolis}

Due to the disparities in the distribution of maternal health care resources, the rate of maternal death was examined. It was found that a large number of maternal deaths occur in Ibadan North in spite of the presence of a large supply of public maternal health care facilities and skilled maternal health care workers. Ibadan North has the highest maternal mortality rate (1,171.68 maternal deaths per 100,000 live births) compared to Ibadan Southwest (47.13 maternal deaths per 100,000 live births) and Akinyele (78.43 maternal deaths per 100,000 live births) Local Government Areas which have the lowest rate of maternal death (Table 5). 
Table 5: Maternal Mortality Rate by Local Government Area in Ibadan

\begin{tabular}{|c|c|c|c|}
\hline $\begin{array}{l}\text { Local } \\
\text { Government } \\
\text { Area }\end{array}$ & $\begin{array}{l}\text { No of } \\
\text { Live } \\
\text { Births* }\end{array}$ & $\begin{array}{l}\text { No of } \\
\text { Maternal } \\
\text { Deaths* }\end{array}$ & $\begin{array}{c}\text { Maternal } \\
\text { Mortality Rate } \\
\text { per } 100,000 \text { Live } \\
\text { Births }\end{array}$ \\
\hline Akinyele & 1,275 & 1 & 78.43 \\
\hline Egbeda & 1,482 & 2 & 134.95 \\
\hline Ibadan North & 3,926 & 46 & $1,171.68$ \\
\hline Ibadan NE & 3,596 & 3 & 83.43 \\
\hline Ibadan NW & 1,526 & 7 & 458.72 \\
\hline Ibadan SE & 4,331 & 6 & 138.54 \\
\hline Ibadan SW & 2,122 & 1 & 47.13 \\
\hline Ido & 736 & 0 & 0 \\
\hline Lagelu & 697 & 2 & 286.94 \\
\hline Oluyole & 780 & 5 & 641.03 \\
\hline Ona-Ara & 1,474 & 7 & 474.89 \\
\hline \multicolumn{4}{|c|}{$\begin{array}{l}\text { *Averages for 2009-2011 } \\
\text { Source: Author's Calculations (2013) based on data from } \\
\text { the Oyo State Ministry of Health, Nigeria. }\end{array}$} \\
\hline
\end{tabular}

However, this can easily be explained by the fact that the only two tertiary facilities are located there hence women with pregnancy related complications are largely referred to both facilities. However several factors such as poverty, poor referral health care system, poor transportation networks, lack of ambulances and other supporting medical equipments etc. could be contributing to type 2 and 3 delays thus leading to the death of such women before they are referred, enroute to these facilities or shortly after their arrival. It is however likely that many more women die from maternal related causes outside of public maternal health care facilities. However, the exact figure is not known because of poor record keeping and management on the part of government maternal health care facilities and registration centers as well as the cultural barriers, fear of legal prosecution and ignorance which discourages individuals from reporting such deaths.

Rank correlation results $(r s=0.07$ ) show little or no correlation between the rate of maternal mortality and the number of maternal health care workers in Ibadan. Initially, it was assumed that high values of maternal mortality in Ibadan North LGA could be unduly influencing results hence rank correlation analysis was also carried out with the exclusion of Ibadan North. However, results ( $r s=-0.47$ ) indicate a moderate negative though insignificant correlation between maternal mortality rates and the number of skilled maternal health care workers in Ibadan city. Similarly, results ( $r s=-0.51$ ) indicate a moderate negative but insignificant correlation between the rate of maternal mortality and the number of public maternal health care facilities in Ibadan. All three results show that maternal mortality rates are not influenced in any significant way by either the number of maternal health care workers or the number of public maternal health care facilities in Ibadan. However, this does not 
mean that the supply of both maternal health care facilities and workers is not important. The results obtained from this study may be due to the fact that incidents of maternal mortality are often under reported. Improving the adequacy and overall coverage of public maternal health care facilities and health care workers should still be a major priority in the planning of maternal health care in Ibadan.

\section{CONCLUSION}

Clearly, some Local Government Areas in Ibadan have a fairly adequate supply of public maternal health care facilities when compared to the number of women of child bearing age but a poor level of availability or coverage when compared to land size. Such differences can be explained by the population of women aged 15-49 years and the size of the land area these facilities serve. As a result Local Government Areas such as Ido, Akinyele and Oluyole have an adequate number of public maternal health care facilities in relation to the target population. However, they are largely primary maternal health care facilities and physical access to them is poor. On the other hand, some Local Government Areas such as Ibadan North, Southeast and Northeast have public maternal health care facilities that are inadequate for the population of women aged 15-49 years resident there. However, available facilities are likely to be much more accessible because of their smaller catchment area as indicated by the small land area per facility. Ona-Ara and Lagelu Local Government Area have a poor level of availability of public maternal health care facilities both in relation to the population of women aged 15-49 years and land area. In other words, not only are public maternal health care facilities inadequate, they are also poorly located. The poor supply and distribution of public maternal health care services could be addressed by taking into consideration the population of women aged 15-49 years and the land areas of the Local Government Areas in locating new facilities. It is also important for the Government to carry out extensive campaigns to educate the public of the importance of recording deaths especially maternal deaths. Public maternal health care facilities must also be encouraged to keep up to date records of patients, staff and medical resources and ensure that such up to date records are forwarded to the relevant Government and Research agencies. Most importantly, there is a need to establish an efficient health care information system for the efficient collection, processing and management of data. Government maternal health care agencies could also collaborate more with traditional health care centers through improving and monitoring their quality of service and incorporating them in the maternal health care referral system. This will make maternal health care accessible to people living in the rural and peri-urban areas of Ibadan metropolis.

\section{REFERENCES}

AYENI,B AND RUSHTON,G (1985) Distributional Equity and Efficiency in the Locational Analysis of Public Facilities: A Case Study. The Nigerian Geographical Journal Vol 28 and 29, No 1 and 2 pp $115-135$. 
AYOADE, M.A (2014) Spatial Accessibility to Public Maternal Health Care Facilities in Ibadan, Nigeria. The International Journal of Social Sciences Vol. 26, No 1 pp 13-28.

COMBER, A.J et al (2011) A Spatial Analysis of Variations in Health Access: Linking Geography, Socio-economic Status and Access Perceptions. International Journal of Health Geographics 10:44. http://dx.doi.org/10.1186/1476-072X-10-44

DASKIN, M.S AND DEAN,L.K (2004) Location of Health Care Facilities in Sainfort,F; Brandeau,M and Pierskalla,W (EDs), A Handbook of Methods and Applications, pp. 43-76.

GUAGLIARDO, M.F (2004) Spatial Accessibility of Primary Care: Concepts, Methods and Challenges. International Journal of Health Geographics, 3:3. http://dx.doi.org/10.1186/1476-072X-3-3

GUPTA, $N$ et al (2011)Human Resources for Maternal, Newborn and Child Health: From Measurement and Planning to Performance for Improved Health Outcomes. Human Resources for Health 9:16 pp 1-11. http://dx.doi.org/10.1186/1478-4491-9-16

HIGGS,G(2004) A Literature Review of the Use of GIS-Based Measures of Access to Health Care Services. Health Services and Outcomes Research Methodology Vol 5, pp 119-139. http://dx.doi.org/10.1007/s10742-005-4304-7

IKPORUKPO, C.O (1987) An Analysis of the Accessibility of Public Facilities in Nigeria. Socioeconomic Planning Sciences Vol. 21, Issue 1, pp 61-69.

MAGUNS, O.O (2008) Problems of Effective Primary Health Care Delivery in Owan East and Owan West Local Government Areas of Edo State, Nigeria. Journal of Social Sciences 16(1), pp 6977.

MAINARDI, S (2007) Unequal Access to Public Healthcare Facilities: Theory and Measurement Revisited. Surveys in Mathematics and its Applications Vol 2, pp 91-112.

MARSH, M.T (1994) Equity Measurement in Facility Location Analysis: A Review and Framework. European Journal of Operational Research 74, pp 1-17. http://dx.doi.org/10.1016/03772217(94)90200-3

NATIONAL POPULATION COMMISSION (2004) Nigeria Demographic and Health Survey,2003 Federal Republic of Nigeria. ORC Macro Calverton, Maryland, USA.

NATIONAL POPULATION COMMISSION (2009) Nigeria Demographic and Health Survey,2008 Federal Republic of Nigeria. ORC Macro Calverton, Maryland, USA.

OKAFOR, F.C (1990) The Spatial Dimensions of Accessibility to General Hospitals in Rural Nigeria. Socio-Economic Planning Services Vol. 24, Issue 4: 295-306.

OKAFOR, S.I (1991) Distributive Effects of Location: Government Hospitals in Ibadan. Area Vol 23, No 2, pp 128-135.

OKAFOR,S.I (2012) Spatial Aspects of Social Service Provision in Nigeria. Department of Geography, University of Ibadan, Ibadan.

SHARMA,N ET AL(2009) A Descriptive Study on Availability of Skilled Birth Attendants (Nursing Personnel and Health Workers Female) in Chandigarh City. Nursing and Midwifery Research Journal, Vol-5, No. 2, pp 59-68.

WHO, UNICEF, UNFPA and World Bank (2010) Trends in Maternal Mortality: 1990-2008.

WHO (2005) World Health Statistics 2005.

WHO (2005) The World Health Report 2005: Make Every Mother and Child Count.

WHO (2006) World Health Statistics 2006. 
WHO (2007) World Health Statistics 2007.

WHO (2009) Women and Health: Today's Evidence, Tomorrows Agenda.

WHO (2014) Trends in Maternal Mortality, 1990 to 2013: Estimates by WHO, UNICEF, UNFPA, The World Bank and The United Nations Population Division. 